\title{
SAMPAR DAN SASALAD: MUSIBAH DALAM SASTRA TELAAH ANALISIS FRAMING
}

\author{
Sampar and Sasalad: Disaster Reflection on Literary through the Framming Analysis \\ Resti Nurfaidah \\ Balai Bahasa Provinsi Jawa Barat \\ Jalan Sumbawa Nomor 11, Bandung 40113 \\ E-mail: sineneng1973@gmail.com
}

\begin{abstract}
COVID-19 was considered a great shock to the world's population. Modern times seemed unable to accept the pandemic. Almost a century ago, the world was hit by the plague and the Spanish flu. History had recorded a repeat of the pandemic by causing other types of diseases until the era of COVID-19. Sampar (Albert Camus) and Sasalad (Dadan Sutisna) were two novels that told a massive story about the history of pandemics. The settings for the two novels were different, one in Europe and one in Garut. However, this paper would explore the common threads that were interwoven in the theme of the disaster in the two novels using a framming analysis knife. The hypotheses found in both sources included (1) the disaster was related to the human lifestyle, and (2) the disaster was related to, and, also, caused many terrible impacts on the social environment.
\end{abstract}

Keywords: Sampar, Sasalad, disaster, pandemic, dan framming

\begin{abstract}
Abstrak
COVID-19 dianggap sebagai sesuatu yang mengejutkan bagi penduduk dunia. Zaman modern seolah tidak dapat menerima pandemi tersebut. Padahal, hampir seabad lalu, dunia pernah didera penyakit sampar dan flu Spanyol. Sejarah mencatat ulangan pandemi dengan memunculkan jenis penyakit lain hingga sampai pada era COVID-19. Sampar (karya Albert Camus) dan Sasalad (karya Dadan Sutisna) merupakan dua novel yang bercerita kental tentang sejarah pandemi. Latar kedua novel itu tentu berbeda, satu di Eropa dan satu di Garut. Namun makalah ini akan menelusuri benang merah yang terjalin dalam tema musibah pada kedua novel itu dengan menggunakan pisau analisis framming. Hipotesis yang didapati dalam kedua sumber data itu, antara lain, (1) musibah itu berkaitan dengan pola hidup manusia, serta (2) musibah itu berkaitan dengan dan berdampak pada lingkungan sosial.
\end{abstract}

Kata kunci: Sampar, Sasalad, musibah, pandemi, dan framming

\section{PENDAHULUAN}

Bencana atau musibah merupakan hal-hal yang sangat tidak diinginkan oleh manusia karena akan menimbulkan serangkaian dampak buruk, seperti kesulitan, kesedihan, kehilangan, keburukan, kerusakan, atau kerugian. Namun, kedua hal itu merupakan bagian dari suratan takdir yang kedatangannya, pada umumnya, tidak pernah dapat diduga oleh seseorang. Bencana atau musibah terkadang membuka banyak praduga dan pascaduga. Tidak jarang, bencana itu dikaitkan dengan mitos atau kutukan. Menariknya peristiwa kedua hal itu kerap kali diangkat sebagai tema dalam karya 
sastra. Sebutlah salah satu karya Ahmad Tohari yang sangat legendaris, Trilogi Ronggeng Dukuh Paruk, yang menyampaikan dampak dari sebuah habitus pola makan di sebuah kampung terpencil yang miskin, Dukuh Paruk (Tohari, 2003). Kebiasaan memakan tempe bongkrek, salah satu makanan khas yang berasal dari daerah Banyumas, Jawa Tengah. Makanan tersebut terbuat dari ampas kedelai dan bungkil kelapa yang difermentasi menghasilkan olahan berwarna hitam. Sayangnya, olahan tradisional tersebut kerap kali menimbulkan dampak keracunan yang cukup hebat. Berkali-kali pula di negeri ini terjadi peristiwa keracunan tempe bongkrek (Setiawan, 2020). Namun, sampai saat ini, kebiasaan menyantap makanan tersebut tetap dilakukan (Amemoar, 2020).

Tsunami yang menyerang wilayah Aceh dan beberapa negara di Asia Selatan, pada 26 Desember 2004, cukup menyesakkan dada. Tere Liye dengan jeli menangkap penderitaan para korban tsunami dalam sebuah novel berjudul Hafalan Surat Delisa, berdasarkan kisah nyata yang dialami oleh seorang gadis cilik bernama Delisa (Tere Liye, 2005: 3--335). Pada saat itu, Delisa harus kehilangan ibu kandung, beberapa kakak, dan sahabatnya. Selain itu, Delisa mengalami cedera patah kaki yang cukup parah akibat benturan keras pada saat hanyut diterpa tsunami. Delisa sarat mengajarkan reigiusitas, di antaranya, bahwa peristiwa berat itu harus dihadapi dengan ketabahan, serta rasa kasih yang didasari dengan keihklasan.

Karya sastra bertemakan musibah yang akan dibahas dalam makalah ini adalah dua novel berjudul Sampar (Camus, 2013) dan Sasalad (Sutisna, 2020). Novel Sampar merupakan karya legendaris. Bahasan tentang novel tersebut cukup banyak, di antaranya, Dian Endah Utami dalam artikel berjudul "Absurditas dalam Novel Sampar Karya Albert Camus", memaparkan konsep absurditas dalam novel Sampar tersebut (Utami, 2018, pp. 2-11). Utami menyampaikan bahwa unsur absurd yang kental dalam novel tersebut ditujukan untuk memberikan gambaran tentang manusia sebagai individu yang bertanggungjawab atas kemauannya yang bebas tanpa memikirkan secara mendalam mana yang benar dan mana yang tidak benar. Absurditas mempermainkan pembaca antara dunia fiksi dan realitas. Tidak mengherankan jika karya sastra absurd merupakan karya sastra yang tidak masuk akal, susah diduga dalam memainkan tokohtokohnya karena pandangan, pemikiran, atau gaya pengarangnya. Hilal Iqbal dan Widodo Mulyanto dalam artikel berjudul "Eksistensi Tiga Tokoh Sampar dalam Menghadapi Absurditas" menyampaikan konsep absurditas yang difokuskan pada ketiga tokoh utama dalam novel Sampar, yaitu Rieux, Paneloux, dan Cottard (Hilal, Iqbal, dan Widodo, 2015, pp. 20-31). Hasil penelitian menunjukan bahwa ketiga tokoh itu mengalami absurditas dalam bentuk penderitaan, keterasingan, kegagalan, dan kematian dengan cara yang berbeda sesuai dengan visi yang diemban masing-masing. Haryatmoko menyampaikan bahwa penggambaran konsep pandemi dalam novel tersebut sangat luar biasa melalui otonomisasi teks, yaitu teks yang mampu lepas dari keinginan penulisnya sendiri, bahkan dapat menyesuaikan dengan kondisi pada masa yang berbeda (SAV PUSKAT, 2018). Ketiga contoh penelitian tadi tidak dapat melepaskan diri dari konsep absurditas dalam filsafat eksistensialisme, yang 
menyampaikan geliat kesadaran manusia akan dirinya, dunia sekitar, berdasarkan bencana yang terjadi di Kota Oran, Aljazair. Novel Sasalad baru saja di luncurkan pada September 2020 lalu. Kajian akademis terhadap novel tersebut belum dilakukan. Jika dilakukan pencarian, ditemukan beberapa munculan berupa sinopsis pendek tentang novel Sasalad tersebut. Novel Sasalad dipilih dengan satu kesamaan tema pada novel Sampar, yaitu pandemi penyakit pes pada era 1920-1930-an di seluruh dunia. Dalam Sasalad, Sutisna (2020: 1-300) mengangkat romantisme tokoh Sutaya dan Andasih berupa cinta yang penuh perjuangan dengan dilatari masa pandemi penyakit sampar atau pes di Kota Garut. Sasalad dalam bahasa Sunda berarti wabah atau pandemi. Tokoh dalam novel tersebut, selain, menghadapi masa pandemi bersama, pada waktu yang bersamaan, harus menghadapi pandemi dalam diri masing-masing. Meskipun terdapat dua perbedaan tahun penulisan, sebelum pandemic Corona, dua novel tersebut menyampaikan kondisi pandemi Corona, seperti keraguan dan ketidakpercayaan masyarakat, sikap pemerintah yang dianggap tidak kompeten menangani pandemi, serta sikap media yang kerap menggambarkan kerancuan.

Penelitian tentang musibah dalam kedua novel itu dikaitkan dengan pola hidup manusia serta lingkungan dan sikap sosial. Penelitian ini bersifat kualitatif dengan pendekatan deskriptif komparatif. Pengambilan data dilakukan dengan pengamatan dan perbandingan cermat pada dua sumber data primer berupa novel Sampar karya Albert Camus dan novel Sasalad karya Dadan Sutisna. Data sekunder diperoleh dengan tambahan informasi tentang pandemi penyakit sampar/pes dari berbagai literatur pendukung penelitian berupa buku, media informasi, portal penelitian, baik manual maupun elektronik. Konsep teoretis yang dipakai adalah framing. Konsep tersebut sejatinya digunakan untuk membingkai berita, peranan berita dalam pembentukan tentang interpretasi media, serta pengaruh berita terhadap masyarakat (Ambar, 2017). Framing kerap kali digunakan dalam bidang komunikasi, politik, atau gerakan sosial. Namun, pada beberapa kali pengamatan cermat, konsep tersebut juga dapat diaplikasikan pada bidang lain,seperti dalam penelitian sastra dan budaya. Cara pandang cultural studies memungkinkan aplikasi teori tersebut dalam penelitian ini. Dari beberapa konsep framing yang ada, framing Pan dan Konsicki dapat diadaptasikan dengan mengoperasionalkan keempat dimensi struktural teks berita sebagai perangkat framing, yaitu sintaksis, skrip, tematik, dan retoris, seperti dalam tabel 1 berikut (Pan, Zhongdang, dan Konsicki, 1993, pp. 55-75).

Tabel 1. Empat dimensi sruktural teks Pan \& Kosicki

\begin{tabular}{cll}
\hline STRUKUR & \multicolumn{1}{c}{ PERANGKAT FRAMING } & \multicolumn{1}{c}{ UNIT TESTED } \\
\hline SINTAKSIS & News scheme & $\begin{array}{l}\text { Headline, lead, background information, quotes, } \\
\text { sources, statements, conclusions }\end{array}$ \\
\hline SKRIP & News comphrehensiveness & $5 \mathrm{~W}+1 \mathrm{H}$ \\
\hline TEMATIK & $\begin{array}{l}\text { Detail, sentence intentions and its relations, } \\
\text { nominalisation between sentences, coherence, } \\
\text { sentence form, pronouns }\end{array}$ & Paragraph, proposition \\
\hline RETORIS & lexicon, graphics, metaphors, presuppositions & Words, idioms, pictures, graphics \\
\hline
\end{tabular}

Sumber: Eriyanto (2002: 256) 
Kolom sintaksis dikaitkan dengan judul utama sumber data atau sumber informasi utama (Eriyanto, 2002). Kolom skrip merupakan informasi tambahan tentang sumber data berupa pertanyaan $5 \mathrm{~W}+1 \mathrm{H}$ (who, when, what, why, where, dan how). Kolom tematik berisi detail data, misalnya kutipan yang mendukung hasil penelitian. Kolom retoris berisi hal-hal yang dipentingkan dalam data pada kolom tematik. Dalam Aprinta (hlm. 16), disampaikan bahwa hasil akhir konsep framing adalah representasi (Aprinta, 2011).

\section{PEMBAHASAN}

\section{Sebab Pandemi}

Baik dalam Sampar maupun Sasalad menyampaikan bahwa sebab timbulnya pandemi adalah melonjaknya populasi tikus di wilayah setempat (tabel 2). Kata paudagudag menunjukan tinggi dan cepatnya angka kematian tikus yang terkontaminasi bakteri penyebab penyakit pes, yaitu Yersinia Pestisia yang disebarkan oleh kutu pada tubuh tikus (Willy, 2018). Populasi tikus sebagai agen penyakit pes yang tidak terkendali menyebabkan mudahnya penularan penyakit tersebut. Bangkai-bangkai yang bermunculan sebenarnya didukung oleh pola hidup dan lingkungan yang kurang baik.

Tabel 2. Sebab Pandemi

\begin{tabular}{|c|c|c|c|}
\hline STRUKUR & PERANGKAT FRAMING & \multicolumn{2}{|c|}{ UNIT TESTED } \\
\hline SINTAKSIS & News scheme & Sasalad & Sampar \\
\hline SKRIP & News comphrehensiveness & $\begin{array}{l}\text { Penulis: Dadan Sutisna } \\
\text { Penerbit: Pustaka Jaya } \\
\text { Tema: musibah berupa pandemi }\end{array}$ & $\begin{array}{l}\text { Penulis: Albert Camus } \\
\text { Penerbit: Pustaka Obor } \\
\text { Indonesia (edisi terjemahan) } \\
\text { Tema: musibah berupa pandemi }\end{array}$ \\
\hline TEMATIK & $\begin{array}{l}\text { Detail, sentence intentions and } \\
\text { its relations, nominalisation } \\
\text { between sentences, coherence, } \\
\text { sentence form, pronouns }\end{array}$ & $\begin{array}{l}\text { Beurit nu paraêh têh itunganana } \\
\text { kawas paudag-udag jeung } \\
\text { urang lembur nu ngaleupaskeun } \\
\text { nyawa. (Sutisna, 2020:211) } \\
\text { Jumlah tikus yang mati saling } \\
\text { berlomba dengan jumlah korban } \\
\text { penyakit pes yang mati. }\end{array}$ & $\begin{array}{l}\quad \text { Kira-kira sejak waktu itulah } \\
\text { penduduk kota kami mulai } \\
\text { khawatir. Karena } \\
\text { sesungguhnyalah mulai tanggal } \\
\text { 16, pabrik-pabrik dan gudang- } \\
\text { gudang memuntahkan ratusan } \\
\text { bangkai tikus. Tidak jarang } \\
\text { penduduk terpaksa membunuh } \\
\text { yang terlalu lama sekarat. Mulai } \\
\text { dari kawasan pinggiran sampai } \\
\text { ke tengah kota, ke mana pun } \\
\text { Dokter Rieaux lewat, di mana } \\
\text { pun penduduk berkumpul, selalu } \\
\text { ada tikus bertumpukan. Baik di } \\
\text { tempat-tempat sampah, maupun } \\
\text { berderetan memanjang di } \\
\text { selokan-selokan. Mulai hari itu } \\
\text { surat kabar sore memuat berita } \\
\text { tersebut. (Camus, 2020: } 16 \text {-17) }\end{array}$ \\
\hline RETORIS & $\begin{array}{l}\text { lexicon, graphics, metaphors, } \\
\text { presuppositions }\end{array}$ & $\begin{array}{l}\text { - } \quad \text { itunganana kawas } \\
\text { paudag-udag }\end{array}$ & $\begin{array}{ll}- & \text { pabrik-pabrik dan } \\
& \text { gudang-gudang } \\
\text { memuntahkan ratusan } \\
\text { bangkai tikus } \\
\text { - } \\
\text { terpaksa membunuh } \\
\text { yang terlalu lama } \\
\text { sekarat } \\
\end{array}$ \\
\hline
\end{tabular}

Sumber: Analisis penulis 
Pada tabel 3 berikut ditunjukkan bahwa sanitasi serta pola hidup yang buruk semakin mempercepat penyebaran penyakit yang berbahaya itu. Tingkat perekonomian dan pendidikan yang rendah, ketimpangan sosial yang tinggi, serta feodalisme yang cukup kental semakin memperburuk situasi. Jangankan untuk memberikan pengetahuan dan sosialisasi kesehatan atau kesadaran diri, seballiknya, pihak berwenang seolah berjarak dengan warga kampung. Dalam Sampar, tidak disebutkan hal serupa, melainkan kondisi lingkungan yang gersang, sehingga kepak burung pun tidak terdengar karena tidak terdapat pepohonan tempat hinggap mereka di tempat itu. Namun, Kota Oran sebagai bagian dari wilayah jajahan Prancis, masih menyisakan nuansa imperialisme dengan hadirnya pabrik-pabrik yang menyisakan sampah dan lahan baru untuk berkembang biak bagi binatang pengerat itu.

Tabel 3. Pola Hidup dan Lingkungan Buruk

\begin{tabular}{|c|c|c|c|}
\hline STRUKUR & PERANGKAT FRAMING & \multicolumn{2}{|c|}{ UNIT TESTED } \\
\hline SINTAKSIS & News scheme & Sasalad & Sampar \\
\hline SKRIP & News comphrehensiveness & $\begin{array}{l}\text { Penulis: Dadan Sutisna } \\
\text { Penerbit: Pustaka Jaya } \\
\text { Tema: musibah berupa pandemi }\end{array}$ & $\begin{array}{l}\text { Penulis: Albert Camus } \\
\text { Penerbit: Pustaka Obor } \\
\text { Indonesia (edisi terjemahan) } \\
\text { Tema: musibah berupa pandemi }\end{array}$ \\
\hline TEMATIK & $\begin{array}{l}\text { Detail, sentence intentions and } \\
\text { its relations, nominalisation } \\
\text { between sentences, coherence, } \\
\text { sentence form, pronouns }\end{array}$ & $\begin{array}{l}\text { Hanjakalna têh, urang dieu mah } \\
\text { tara pati daêk ngurus imah. } \\
{[\ldots]} \\
\text { Mun usum ngijih, lebah buruan } \\
\text { rarujit ku cihujan. Hayam jeung } \\
\text { entog rendang, sawareh hanjat } \\
\text { ka tepas, ngadon modol. Lain } \\
\text { ukur hayam, da urang dieu mah } \\
\text { miceun têh sangareunahn baê. } \\
\text { Aya nu ngali taneuh di } \\
\text { tukangeun imah, nagog dina } \\
\text { cukang solokan, ngajegang dina } \\
\text { tunggul awi, sakalieun aya nu } \\
\text { boga pacilingan gê, unggal isuk } \\
\text { diroronan ku welasan jelema. } \\
\text { (Sutisna, 2020: 183) } \\
\text { Sayangnya, penduduk di } \\
\text { kampung ini kurang senang } \\
\text { mengurus rumah. } \\
\text { [...] } \\
\text { Pada saat musim penghujan, } \\
\text { halaman rumah tampak becek } \\
\text { karena genangan air hujan. } \\
\text { Ayam dan itik berenang, } \\
\text { sebagian naik ke teras dan buang } \\
\text { air di sana. Bukan hanya ayam, } \\
\text { penduduk kampung juga masih } \\
\text { buang kotoran seenaknya: ada } \\
\text { yang menggali tanah, ada yang } \\
\text { jongkok di tepi solokan, ada } \\
\text { yang meregangkan kakinya di } \\
\text { antara rumpun bambu. Kalau } \\
\text { pun ada yang memiliki jamban, } \\
\text { setiap hari akan direcoki belasan } \\
\text { tetangga. }\end{array}$ & $\begin{array}{l}\text { Harus diakui bahwa } \\
\text { kotanya sendiri tidak bagus, } \\
\text { tapi kelihatan tenang. Sebab } \\
\text { itu dibutuhkan waktu yang } \\
\text { cukup lama untuk menyadari } \\
\text { apa yang membedakan Kota } \\
\text { Oran dari kota bisnis di mana } \\
\text { pun. Misalnya, bagaimana } \\
\text { membayangkan sebuah kota } \\
\text { tanpa burung merpati, } \\
\text { pepohonan atau taman dan } \\
\text { halaman. Di sana tidak } \\
\text { terdengar kepak sayap } \\
\text { maupun gemerisik daun-daun. } \\
\text { Pendek kata, sebuah tempat } \\
\text { tanpa ekspresi. (Camus, 2020: } \\
\text { 3) }\end{array}$ \\
\hline
\end{tabular}




\begin{tabular}{|c|c|c|c|}
\hline RETORIS & $\begin{array}{l}\text { lexicon, graphics, metaphors, } \\
\text { presuppositions }\end{array}$ & $\begin{array}{ll}\text { - } & \text { tara pati daêk ngurus } \\
& \text { imah } \\
\text { - } & \text { rarujit ku cihujan } \\
\text { - } & \text { miceun têh } \\
& \text { sangareunahn baê } \\
\text { - } & \text { diroronan ku welasan } \\
\text { jelema }\end{array}$ & $\begin{array}{ll}\text { - } & \text { sebuah kota tanpa } \\
\text { burung merpati, } \\
\text { pepohonan atau } \\
\text { taman dan halaman } \\
\text { tidak terdengar } \\
\text { kepak sayap } \\
\text { maupun gemerisik } \\
\text { daun-daun } \\
\text { sebuah tempat tanpa } \\
\text { ekspresi }\end{array}$ \\
\hline
\end{tabular}

Sumber: Analisis penulis

\section{Sikap Penduduk dan Pihak Berwenang}

Ketertinggalan dan kebodohan yang dialami oleh penduduk kampung menyebabkan sulitnya penanganan penyakit pes. Petugas kesehatan mendapatkan kendala yang luar biasa ketika harus menghapus kepercayaan penduduk terhadap mitos tikus (tabel 4). Tingginya pengaruh para dukun dan penganut aliran kepercayaan, salah satunya kepercayaan pada ilmu hitam, serta pengaruh pihak-pihak yang ingin mengacaukan upaya pemerintah dalam investigasi penyakit tersebut semakin memperkeruh situasi saat itu. Penduduk yang telah terbiasa dengan tradisi kepercayaan tradisionalnya, ditunjang dengan pengaruh dari pihak-pihak yang demikian, lebih memilih bahwa mitos tikus dedemit sebagai penyebab penyakit. Jika banyak tikus mati, mereka percaya bahwa dedemit tikus itu akan terdesak ${ }^{1}$. Hal yang berbeda, ditunjukkan dalam novel Sampar, yaitu penduduk yang sudah tumbuh dalam budaya berpikir logis, terutama setelah Aljazair menjadi koloni Perancis. Sikap bertindak dan berpikir logis itu tampak dalam sikap tokoh dr. Rieaux. Satu ekor tikus yang mati, disikapi dokter tersebut dengan cepat. Sebagai seorang dokter, tentu saja, ia paham reaksi yang akan terjadi pada seekor bangkai dan dampak yang ditimbulkan setelah kematiannya.

Tabel 4. Mitos Tikus

\begin{tabular}{|c|c|c|c|}
\hline STRUKUR & PERANGKAT FRAMING & \multicolumn{2}{|c|}{ UNIT TESTED } \\
\hline SINTAKSIS & News scheme & Sasalad & Sampar \\
\hline SKRIP & News comphrehensiveness & $\begin{array}{l}\text { Penulis: Dadan Sutisna } \\
\text { Penerbit: Pustaka Jaya } \\
\text { Tema: musibah berupa pandemi }\end{array}$ & $\begin{array}{l}\text { Penulis: Albert Camus } \\
\text { Penerbit: Pustaka Obor } \\
\text { Indonesia (edisi terjemahan) } \\
\text { Tema: musibah berupa pandemi }\end{array}$ \\
\hline TEMATIK & $\begin{array}{l}\text { Detail, sentence intentions and } \\
\text { its relations, nominalisation } \\
\text { between sentences, coherence, } \\
\text { sentence form, pronouns }\end{array}$ & $\begin{array}{l}\quad \text { Beurit mah da nyampak di } \\
\text { mamana. Jadi hêsê di basmina. } \\
\text { Ku urang lembur mimindengna } \\
\text { mah diantep karepkeun baê. } \\
\text { Sanajan dikepung nepi ka } \\
\text { liangna, hiji mangsa bakal } \\
\text { datang deui. Teu êcês nu mana- } \\
\text { manana deuih, da di lembur } \\
\text { mah beurit têh rêa naker. Aya } \\
\text { beurit huma nu suku tukangna } \\
\text { mancrit, beurit sawah nu } \\
\text { caricing deukeut cai, beurit } \\
\text { imah nu buntutna panjang, } \\
\text { beurit tangkal nu buluna semu } \\
\text { koneng, jeung beurit dedemit nu }\end{array}$ & $\begin{array}{l}\text { Pagi tanggal } 16 \text { April, ketika } \\
\text { Dokter Bernard Rieaux keluar } \\
\text { dari tempat praktek, kakinya } \\
\text { tersandung seekor tikur mati di } \\
\text { ruang tunggu depan pintu. Pada } \\
\text { waktu itu, tanpa perhatian dia } \\
\text { singkirkan binatang tersebut, } \\
\text { lalu menuruni tangga. Tetapi, } \\
\text { ketika sampai di jalan, dia } \\
\text { berpikir bahwa tikus itu tidak } \\
\text { semestinya berada di sana. Dia } \\
\text { berbalik untuk memberi tahu } \\
\text { penjaga. (Camus, 2020: 8) }\end{array}$ \\
\hline
\end{tabular}




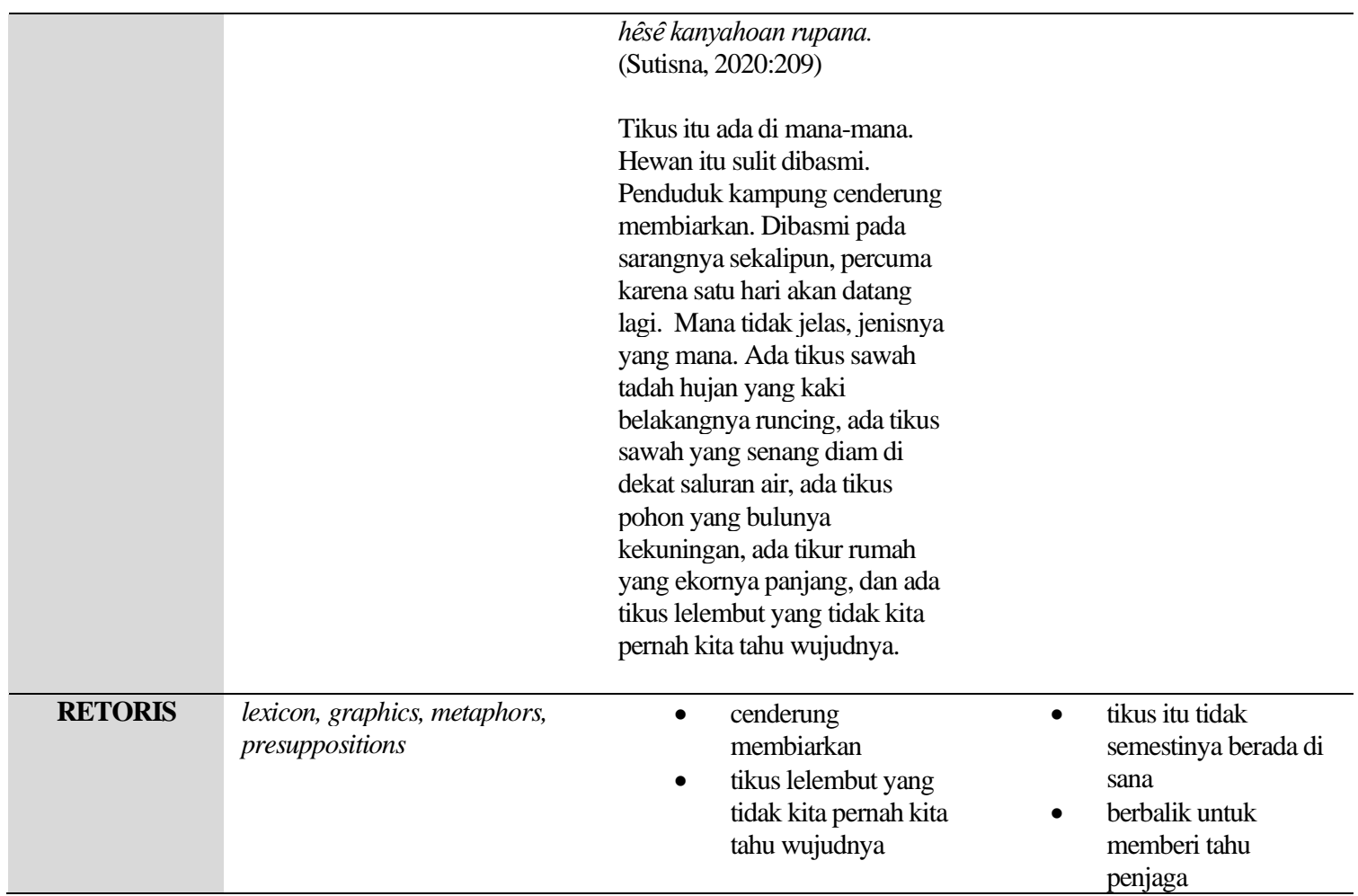

Sumber: Analisis penulis

Pada tabel 5, kesalahpahaman pada ketentuan pemerintah, ditunjang dengan pengetahuan rendah, para penduduk kampung menumbuhkan sikap berprasangka buruk terhadap keputusan pemerintah. Tindakan pemerintah untuk meneliti sebab dan dampak pandemi wabah dianggap sebagai ancaman serius dan eksekusi keji. Bahkan, petugas yang dikitrim oleh pemerintah untuk melakukan penelitian tentang wabah tersebut dianggap sebagai pelaku tindak criminal, tepatnya pembunuh. Pengambilan beberapa sample dari tubuh korban dianggap sebagai siksaan untuk mayat. Puncaknya, penduduk kampung menjadikan pandemi ini sebagai aib keluarga. Kematian anggota keluarga akibat wabah disembunyikan dengan rapat karena jika disampaikan pada para penguasa setempat, si mati akan mengalami siksaan. Dalam catatan Amin sebagaimana dikutip Kurnia (Kurnia, 2020), diungkapkan bahwa pengambilan darah tersebut dianggap sebagai penyiksaan mayat dan menjadi tabu, terlebih keluarga si mati akan dibawa ke sebuah barak yang tempatnya sangat terpencil, sebuah tempat isolasi. Sementara itu, hal yang berbeda ditunjukan dalam novel Sampar. Penggambaran anak kecil yang penurut mencerminkan kepatuhan warga terhadap keputusan pemerintah. Amin juga menyampaikan bahwa banyak pihak yang ditangkap karena diketahui memprovokasi masyarakat untuk menolak perintah dan mengharamkan aturan suntik mayat (Kurnia, 2020). Hoaks pun bermunculan: mantri suntik adalah manusia haus darah, akibatnya, mantri kerap mendapat perlakuan buruk dari masyarakat.

Tabel 5. Doktrin Antipati

\begin{tabular}{clll}
\hline STRUKUR & \multicolumn{1}{c}{ PERANGKAT FRAMING } & & UNIT TESTED \\
SINTAKSIS & News scheme & Sasalad & Sampar \\
SKRIP & News comphrehensiveness & Penulis: Dadan Sutisna & Penulis: Albert Camus \\
\hline
\end{tabular}




\begin{tabular}{|c|c|c|c|}
\hline \multirow{3}{*}{ TEMATIK } & \multirow{3}{*}{$\begin{array}{l}\text { Detail, sentence intentions and } \\
\text { its relations, nominalisation } \\
\text { between sentences, coherence, } \\
\text { sentence form, pronouns }\end{array}$} & $\begin{array}{l}\text { Penerbit: Pustaka Jaya } \\
\text { Tema: musibah berupa pandemi }\end{array}$ & \multirow{3}{*}{$\begin{array}{l}\text { Penerbit: Pustaka Obor } \\
\text { Indonesia (edisi terjemahan) } \\
\text { Tema: musibah berupa pandemi } \\
\quad \text { Anak laki-laki yang sakit } \\
\text { berada di puncak fase } \\
\text { kelemahan, membiarkan diri } \\
\text { diperiksa tanpa mengeluh } \\
\text { (Camus, 2020: 259) }\end{array}$} \\
\hline & & $\begin{array}{l}\text { Ngalawan mantra suntik mah } \\
\text { teu hêsêt teuing.Mun aya nu } \\
\text { maot, kari nyumputkeun baê } \\
\text { layonna, mun perlu dikubur } \\
\text { rerencepan, tukangeun imah } \\
\text { atawa di kolong. (Sutisna, 2020: } \\
210 \text { ) }\end{array}$ & \\
\hline & & $\begin{array}{l}\text { Melawan mantra suntik itu } \\
\text { tidaklah sulit. Jika ada yang } \\
\text { meninggal dunia, cukup } \\
\text { disembunyikan mayatnya. Jika } \\
\text { perlu, mayat tersebut dikubur di } \\
\text { halaman atau di bawah rumah. }\end{array}$ & \\
\hline RETORIS & $\begin{array}{l}\text { lexicon, graphics, metaphors, } \\
\text { presuppositions }\end{array}$ & $\begin{array}{ll}\text { - } & \text { Ngalawan mantra } \\
& \text { suntik } \\
\text { - } & \text { kari nyumputkeun } \\
& \text { baê layonna } \\
\text { - } & \text { dikubur rerencepan }\end{array}$ & $\begin{array}{ll}\text { - } & \text { tikus itu tidak } \\
\text { semestinya berada di } \\
\text { sana } \\
\text { - } \\
\text { berbalik untuk } \\
\text { memberi tahu } \\
\text { penjaga }\end{array}$ \\
\hline
\end{tabular}

Pada tabel 6, kebodohan dan ketidakmampuan dalam menghadapi situasi darurat pandemi, banyak pihak yang turut campur memprovokasi masyarakat. Mandor Sudra menjadi kaki tangan pemerintah kompeni ketika warga perkebunan banyak didera penyakit pes. Mandor Sudra menuntut Andasih untuk menyerahkan tubuhnya sebagai bayaran penutup aib atas kematian ayahnya. Dengan demikian, kematian ayah Andasih tidak akan dilaporkan kepada pimpinan perkebunan dan pemerintah. Tindakan serupa Mandor Sudra tidak lain berakar dari sikap penguasa. Tuan Kontrolir, pemimpin Garut, bersikeras menekan anak buahnya untuk menutup rapat-rapat berita kematian korban pandemi. Kematian massal tersebut dikhawatirkan akan berpengaruh pada kedudukan dan pangkatnya di pemerintahan kolonial ${ }^{2}$. Selain pihak tertentu, media dalam era pandemi juga memilih untuk menjadi corong propaganda. Kondisi perekonomian yang sulit pada masa pandemi tersebut, media tentu terkena dampak juga. Untuk bertahan, media melakukan apa saja, termasuk berita hoak. Dalam Sampar digambarkan sangat berlawanan. Tokoh dr. Rieaux digambarkan bersikap bijak menyampaikan pembenaran ketika ada warga menyampaikan hoaks yang muncul. Sikap cepat tanggap yang ditunjukkan dr. Rieaux meluruskan isu yang muncul dan memompa semangat hidup warganya.

Tabel 6. Doktrinasi

\begin{tabular}{clll}
\hline STRUKUR & PERANGKAT FRAMING & \multicolumn{2}{c}{ UNIT TESTED } \\
\hline SINTAKSIS & News scheme & Sasalad & Sampar \\
\hline SKRIP & News comphrehensiveness & Penulis: Dadan Sutisna & Penulis: Albert Camus \\
& & Penerbit: Pustaka Jaya & Penerbit: Pustaka Obor \\
& & Tema: musibah berupa pandemi & Indonesia (edisi \\
& & & terjemahan) \\
& & & Tema: musibah berupa \\
& & & pandemi \\
\hline TEMATIK & Detail, sentence intentions and & "Mun rêk baralem waê mah, aing gê & "Bagaimana, Dokter? \\
\hline
\end{tabular}




\begin{tabular}{|c|c|c|c|}
\hline & $\begin{array}{l}\text { its relations, nominalisation } \\
\text { between sentences, coherence, } \\
\text { sentence form, pronouns }\end{array}$ & $\begin{array}{l}\text { indit wê ayeuna kênêh," cek Mandor } \\
\text { Sudra bari ngalêngkah ka lebah panto. } \\
\text { Manêhna ngarandeg deui basa kadêngê } \\
\text { andasih ngageroan. } \\
\text { "Tong indit!"' omong Andasih. "Mun teu } \\
\text { inget ka indung jeung anak, aing bakal } \\
\text { milih paêh batan ngaladangan sêtan } \\
\text { bungkeuleukan." (Sutisna, 2020: } 31 \text { ) } \\
\text { "Kalau terus tutup mulut, aku akan pergi } \\
\text { sekarang juga," ujar Mandor Sudra } \\
\text { sambil kakinya melangkah menuju pintu. } \\
\text { Tapi, langkahnya, terhenti ketika } \\
\text { mendengar suara Andasih } \\
\text { memanggilnya. } \\
\text { "Jangan pergi!" kata Andasih, "Kalau } \\
\text { aku tidak ingat ibu dan anakku, lebih } \\
\text { baik aku mati dari pada harus melayani } \\
\text { setan seperti kamu." }\end{array}$ & $\begin{array}{l}\text { Apakah itu penyakit } \\
\text { Korea?" } \\
\text { "Dari mana Anda } \\
\text { mendengar berita } \\
\text { itu?" } \\
\text { "Di surat kabar. } \\
\text { Radio juga } \\
\text { mengatakannya." } \\
\text { "Bukan. Bukan } \\
\text { kolera." } \\
\text { "Bagaimanapun } \\
\text { juga," kata laki-laki } \\
\text { itu bertambah } \\
\text { semangat, "mereka } \\
\text { terlalu melebih- } \\
\text { lebihkan, bukan?" } \\
\text { "Sebab itu, jangan } \\
\text { percaya!" sahut dr. } \\
\text { Rieaux. (Camus, } \\
\text { 2020: 73) }\end{array}$ \\
\hline RETORIS & $\begin{array}{l}\text { lexicon, graphics, metaphors, } \\
\text { presuppositions }\end{array}$ & $\begin{array}{l}\text { - } \quad \text { salah satu bentuk ancaman } \\
\text { yang disampaikan oleh } \\
\text { Mandor Sudra }\end{array}$ & $\begin{array}{ll} & \text { surat kabar } \\
- & \text { radio } \\
- & \text { terlalu } \\
& \text { melebih- } \\
& \text { lebihkan }\end{array}$ \\
\hline
\end{tabular}

Sumber: Analisis Penulis

\section{Tahapan Aksi Pihak Berwenang}

Meskipun ditengarai dengan budaya feodalisme, pihak berwenang melakukan serangkaian tindakan untuk mengatasi masa pandemi. Pada tabel berikut, dalam Sasalad terdapat dualism tindakan, berupa tindakan negatif dan positif. Tindakan negatif muncul pada sikap Mandor dan Tuan Kontrolir yang bersikeras untuk menutupi angka kematian korban pandemi yang cukup tinggi karena kedudukannya takut tergoyahkan. Kondisi tersebut mengakibatkan terbukanya celah di kalangan anak buahnya untuk berbuat yang kurang baik. Mandor Sudra, di antaranya, memanfaatkan kesempatan untuk melakukan pelecehan seksual kepada warganya sendiri. Sementara itu, ada pula tindakan yang positif, yaitu tetua setempat mengerahkan warga laki-laki untuk menjaga batas kampung, dan membentuk kelompok ronda. Sementara itu, atas pemerintah pusat, pemerintahan setempat mengerahkan mantri yang bertugas mengambil specimen bagian tubuh korban untuk diteliti lebih lanjut. Beberapa dokter dengan segenap jiwa dan raga berjuang demi kesembuhan pasien pandemi, meskipun beberapa di antaranya harus berkorban nyawa. Pencanangan program woneng (dari woningen, Bld) atau program penggantian konsep bangunan rumah, dari yang beratap bambu atau rumbia, menjadi beratap genting, di lakukan pada di beberapa wilayah pandemi ${ }^{3 \& 4}$. Hal itu tidak mudah karena berbenturan dengan konsep keyakinan tradisional bahwa atap kenteng dianggap sebagai sumber kematian penghuni rumah. Meskipun warga Kota Oran juga percaya akan ramalan, tetapi mereka mendapatkan dukungan dari pihak berwenang untuk patuh 
dan tetap bersikap biasa dalam mengatasi kehidupan masa pandemik. Pemerintah dengan segala unsur kewenangannya selalu bertindak cepat dan giat menyampaikan halhal penting tanpa menghilangkan ketenangan warganya.

Tabel 7. Tahapan Aksi

\begin{tabular}{|c|c|c|c|}
\hline STRUKUR & PERANGKAT FRAMING & \multicolumn{2}{|c|}{ UNIT TESTED } \\
\hline SINTAKSIS & News scheme & Sasalad & \\
\hline SKRIP & News comphrehensiveness & $\begin{array}{l}\text { Penulis: Dadan Sutisna } \\
\text { Penerbit: Pustaka Jaya } \\
\text { Tema: musibah berupa pandemi }\end{array}$ & $\begin{array}{l}\text { Penulis: Albert Camus } \\
\text { Penerbit: Pustaka Obor } \\
\text { Indonesia (edisi terjemahan) } \\
\text { Tema: musibah berupa pandemi }\end{array}$ \\
\hline TEMATIK & $\begin{array}{l}\text { Detail, sentence intentions and } \\
\text { its relations, nominalisation } \\
\text { between sentences, coherence, } \\
\text { sentence form, pronouns }\end{array}$ & $\begin{array}{l}\text { Sakabêh urang lembur têh } \\
\text { dicaram ninggalkeun imah, kitu } \\
\text { nu kadêngê tadi beurang. } \\
\text { Maranêhna ngagugu kana } \\
\text { omongan Kasja, geus aya poêna } \\
\text { ngarerem manê h di jero imah, } \\
\text { kaluar tê h mun rêk ka cai atawa } \\
\text { nyokot suluh ti kolong. Ari nu } \\
\text { liar kênêh mah estu jelema } \\
\text { teuneung, nu teu sieun ku } \\
\text { kasakit, daêk paêh keur balarêa. } \\
\text { (Sutisna, 2020: 187) }\end{array}$ & $\begin{array}{l}\text { Tindakan-tindakan mereka tidak } \\
\text { ketat. Rupanya mereka } \\
\text { menghindari kepanikan } \\
\text { penduduk Oran. (Camus, 2020: } \\
63 \text { ) }\end{array}$ \\
\hline & & $\begin{array}{l}\text { Seisi kampung diminta untuk } \\
\text { tinggal di rumah, itu yang berita } \\
\text { tadi siang. Penduduk kampung } \\
\text { mematuhi kata-kata Kasja. } \\
\text { Berhari-hari mereka diam di } \\
\text { rumah, kecuali buang hajat atau } \\
\text { mengambil kayu bakar di } \\
\text { kolong rumah mereka. } \\
\text { Kalaupun ada yang berkeliaran, } \\
\text { ya mereka yang berkepentingan, } \\
\text { tidak takut kena penyait, dan rela } \\
\text { berkorban untuk semua orang. }\end{array}$ & $\begin{array}{l}\text { Pastur meneruskan, bahwa apa } \\
\text { yang dia katakana dalam } \\
\text { khotbahnya di mimbar itu juda } \\
\text { beberapa bulan lalu tetap } \\
\text { merupakan kebenaran. Camus, } \\
\text { 2020: 274) }\end{array}$ \\
\hline RETORIS & $\begin{array}{l}\text { lexicon, graphics, metaphors, } \\
\text { presuppositions }\end{array}$ & $\begin{array}{l}\text { - } \quad \text { ngagugu kana omongan } \\
\text { Kasja }\end{array}$ & $\begin{array}{ll}- & \text { menghindari } \\
\text { kepanikan penduduk } \\
\text { Oran } \\
\text { - } & \text { penutupan pintu kota } \\
\text { - } & \text { khotbah dan } \\
\text { kebenaran }\end{array}$ \\
\hline
\end{tabular}

Sumber: Analisis Penulis

\section{SIMPULAN}

Sasalad dan Sampar merupakan "kitab" penggambaran pandemi penyakit pes yang pernah terjadi dalam tempo yang hampir sama. Pihak berwenang dalam kedua novel melakukan tindakan yang berbeda dalam penanganan pandemi. Sasalad menggambarkan dampak feodalisme yang kental, sehingga kesenjangan sosial mengundang tindakan cenderung anarkis dan meningkatkan kepanikan di kalangan warga dalam menghadapi pandemi serta situasi yang menyulitkan. Banyak permainan yang dilakukan oleh pihak-pihak yang memperkeruh suasana. Terlebih tingkat pengetahuan warga yang sangat rendah memudahkan kekacauan terjadi di wilayah yang terkena wabah. Sementara itu, Sampar menunjukkan konsep penanganan dengan dasar akademik dan psikologis yang cukup kental. Penguasa mampu melakukan tindakan 
penanganan pandemi tanpa mengakibatkan kepanikan di kalangan warga. Sebaliknya, warga disarankan untuk tetap waspada, tetapi tetap bersikap gembira dan rileks dalam menghadapi pandemi tersebut.

\section{DAFTAR PUSTAKA}

Ambar. (2017). “Analisis Framing Menurut Para Ahli: Pengertian, Konsep, dan Metode. "dalam https://pakarkomunikasi.com/analisis-framing. (23-12-2020)

Amemoar. (2020). "Sejarah Panjang Tempe Bongkrek yang Setiap Tahunnya Merenggut Puluhan Jiwa." dalam https://www.youtube.com/watch?v=P4tiZw4Ve0k. (23-12- 2020)

Aprinta, G. (2011). "Kajian Media Massa: Representasi Girl Power Wanita Modern dalam Media Online (Studi Framing Girl Power dalam Rubrik Karir dan Keuangan femina Online)." The Messenger, 2(2), 12-27., Januari 2011.

https://doi.org/http://dx.doi.org/10.26623/themessenger.v3i1.179. (23-12- 2020)

Camus, A. (2013). Sampar. Jakarta: Penerbit Obor.

Eriyanto. (2002). Analisis Framing: Konstruksi, Ideologi, dan Politik Media. Yogyakarta: LKIS.

Hilal, Iqbal, dan Widodo, M. (2015). "Eksistensi Tiga Tokoh Sampar dalam Menghadapi Absurditas.” Jurnal Bahasa Dan Sastra: Aksara, Vol. 16 (No. 1), $20-31$.

Kurnia, A. (2020). Jaman Woneng: Jaman Sampar di Priangan, 1925-1973. Garut: Penerbit Layung.

Liye, T. (2005). Hafalan Surat Delisa. Jakarta: Penerbit Republika.

Pan, Zhongdang, dan Konsicki, G. M. (1993). Framing Analysis: An Approach to News Discourse. Political Communication, Volume 10 (Nomor 1), 55-75|.

SAV PUSKAT. 2018. Bincang MoTv bersama Rm. Dr. J. Haryatmoko SJ tentang Sampar-bag. 1 l \#13. Youtube.

Setiawan, A. (2020). “Petaka Tempe Bongkrek.” Historia.Id. (Petaka Tempe Bongkrek | HISTORIA.ID - YouTube)

Sutisna, D. (2020). Sasalad. Bandung: Pustaka Jaya.

Tohari, A. (2003). Ronggeng Dukuh Paruk. Gramedia Pustaka Utama.

Utami, D. E. (2018). “Absurditas dalam Novel Sampar Karya Albert Camus.” SimkiPedagogia, 2(3).

Willy, T. (2018). "Pes.” (Www. Alodokter.Com)

\section{HASIL DISKUSI}

Tidak ada pertanyaan

\footnotetext{
${ }^{1}$ Sutisna, 2020: 209-211

${ }^{2}$ Sutisna, 2020: 245

${ }^{3}$ Sutisna, 2020: 231

${ }^{4}$ Kurnia, 2020: 129-138
} 